Schulich School of Law, Dalhousie University

Schulich Law Scholars

Research Papers, Working Papers, Conference

Papers

Faculty Scholarship

$1-2-2019$

\title{
Environmental Liability for Deep Seabed Mining in the Area: An Urgent Case for a Robust Strict Liability Regime
}

\author{
Keith MacMaster \\ Dalhousie University - Dalhousie University, Schulich School of Law, Students, kemacmas@dal.ca
}

Follow this and additional works at: https://digitalcommons.schulichlaw.dal.ca/working_papers

\begin{abstract}
Recommended Citation
MacMaster, Keith, "Environmental Liability for Deep Seabed Mining in the Area: An Urgent Case for a Robust Strict Liability Regime" (2019). Research Papers, Working Papers, Conference Papers. 14. https://digitalcommons.schulichlaw.dal.ca/working_papers/14
\end{abstract}

This Working Paper is brought to you for free and open access by the Faculty Scholarship at Schulich Law Scholars. It has been accepted for inclusion in Research Papers, Working Papers, Conference Papers by an authorized administrator of Schulich Law Scholars. For more information, please contact hannah.steeves@dal.ca. 


\title{
Environmental Liability for Deep Seabed Mining in the Area: An Urgent Case for a Robust Strict Liability Regime ${ }^{\dagger}$
}

\author{
Keith MacMaster \\ LLM Candidate, Schulich School of Law, Dalhousie University, Halifax, Canada
}

\section{INTRODUCTION}

Protecting the environment, both living and non-living, is important. Mining, too, is important, as it provides the raw products for many of today's "necessities," including cobalt, nickel, and the rare earth metals used in electronics. Deep seabed mining (DSM) is an important and emerging field within the Law of the Sea as countries and companies expand their production of minerals. The International Seabed Area (The Area), which is the seabed and subsoil area beyond national jurisdictions, the subject for this type of mining, was deemed to be the "common heritage of mankind" and outside the jurisdiction of any one State. ${ }^{1}$ This required separate governance structured under Part XI of the United Nations Convention on the Law of the Sea (UNCLOS). ${ }^{2}$

This article will focus on liabilities for the Area and examine the question of liability for the various actors involved, including contractors/operators who carry out the exploitation of resources, sponsoring States, flag States, and the International Seabed Authority. It is necessary to analyze the current state of liability provisions, should environmental damage occur in the Area. The rapid pace of technological advancement and the unknown extent of environmental damage make a fulsome liability regime necessary. Unfortunately, as will be shown in this article, there are still extensive unknowns in the legal landscape.

This article will investigate two areas of liability: the standard of liability (strict, negligence, and whether there is a potential for a due diligence defense, active act, or mens rea requirements) and the extent of liability (limited or unlimited damage claim potentials). The UNCLOS seems to provide for one type of liability for operators, but the subsequent legislation, as will be shown, seems to "water down" liabilities, making a detailed analysis required.

Given the scope of this article, not all areas of liability can be addressed. There are many other areas of liability that need to be assessed in subsequent research, including procedural claims, the types of due diligence defenses, and whether environmental impact assessments and plans of work would fulfill these requirements, the assessment of damages and the ability to pay, and the creation of DSM insurance to handle any liability claims.

This article will be structured as follows. Part 1 will detail the history and context of DSM. Part 2 is subdivided into two sections: the first subsection will detail the current UNCLOS and regulatory state of liability for DSM, while the second subsection will identify gaps in liabilities both from the historical context and from the current governance regime. Part 3 will investigate the domestic legislation of several countries to determine if any gaps are filled by domestic laws, as required by the UNCLOS. ${ }^{3}$ Part 4 will research other maritime liability regimes, including civil liability regimes, to attempt to show how a system could be developed to deal with all aspects of liabilities. Part 5 will synthesize the current research

\footnotetext{
This article was the winning entry in the 2018 Ocean Yearbook Student Paper Competition.

${ }^{1}$ United Nations Convention on the Law of the Sea, Dec. 10, 1982, 1833 United Nations Treaty Series 397, entered into force on Nov. 1, 1994, Article 136; See also M. Lodge, "The common heritage of mankind," The International Journal of Marine and Coastal Law 27 (2012): 733-742.

${ }^{2}$ Id., Part XI.

${ }^{3}$ Given the parameters of this article, it is not possible to canvass every country with an interest in DSM in the Area. Thus, the countries of Singapore, Nauru, Tonga, China, Canada, the U.S.A., and New Zealand will be chosen. Follow-up research will investigate other countries with potential DSM claims, such as the EU, India, Russia, the U.K., and others.
} 
and recommend changes to the development of liability standards, including the creation of an environmental fund.

\section{PART 1 - CONTEXT AND LIABILITY ISSUES}

The Deep Seabed (DSB) extends on the continental shelf, the exclusive economic zone (EEZ), and the Area, and is defined as any seabed surface below $200 \mathrm{~m}^{4}$ It is thought to contain vast quantities of minerals, resources, and potentially oil and gas. ${ }^{5}$ The DSB encompasses not only the Area, but also the continental shelf (CS) and EEZ. ${ }^{6}$ Resources are defined in Article 133 of the UNCLOS as "all solid, liquid or gaseous mineral resources in situ in the Area at or beneath the seabed, including polymetallic nodules." 7 It is believed to be a next frontier for extractive industries, ${ }^{8}$ as it is seen as solving two issues: first, the potential decline in on-shore mineral resources, such as copper and rare-earth metals, and second, that developing countries may benefit from resource extraction as a route to economic development. ${ }^{10}$

DSM has not been a significant issue to date due to a lack of technologies that could exploit the Area. ${ }^{11}$ However, extractive technologies are advancing at a rapid pace and are almost at commercial readiness. ${ }^{12}$ Given that much of the DSB is found at depths of $1.5 \mathrm{~km}$ and commercial quantities from 3000 to $6,000 \mathrm{~m},{ }^{13}$ there is a great risk of environmental damage conducted by any exploration or exploitation.

There was no fulsome regulatory regime for the Area in the UNCLOS. Rather, Part XI created the International Seabed Authority (ISA) to regulate activities. ${ }^{14}$ The ISA may exercise control in the Area, as is necessary, to ensure compliance with Part XI, and all countries are obligated to ensure compliance with Article $139 .{ }^{15}$ The ISA is thus responsible for all DSM in the Area. ${ }^{16}$ To obtain a permit to explore the Area for DSM, a sponsoring state must submit a Plan of Work. ${ }^{17}$ As of the date of this article, twenty eight exploration contracts have been issued by the ISA. ${ }^{18}$ Yet, despite this number of permits, there are several important legal issues related to DSM that have not been fully developed, including both liability and environmental assessment (EA) requirements.

\footnotetext{
${ }^{4}$ M. Lodge, "The International Seabed Authority and deep seabed mining," UN Chronicle 54:2 (2017): 44-46.

${ }^{5}$ A. Jaeckel, J. Ardron and K. Gjerde, "Sharing benefits of the common heritage of mankind: Is the deep seabed mining regime ready?," Marine Policy 70 (2016): 198-204.

${ }^{6}$ UNCLOS provides that the CS and EEZ are within national jurisdiction of States and thus outside the scope of this research

${ }^{7}$ UNCLOS, n. 1 above, Article 133.

${ }^{8}$ International Seabed Authority, "Towards the Development of a Regulatory Framework for Polymetallic Nodule Exploitation in the Area, Technical Study No. 11 (Jamaica: ISA, 2013).

${ }^{9}$ R.E. Kim, “Should deep seabed mining be allowed?" Marine Policy 82 (2017): 134-137, p. 135.

10 L.D. Bolong, "Into the abyss: Rationalizing commercial deep seabed mining through pragmatism and international law," Tulane Law Review 26 (2016): 128-180, p. 132.

${ }^{11}$ R.E. Boschen et al., "Mining of deep-sea seafloor massive sulfides: A review of the deposits, their benthic communities, impacts from mining, regulatory frameworks and management strategies," Ocean \& Coastal Management 84 (2013): 54-67, p. 55.

${ }^{12}$ Id., p. 56.

13 International Seabed Authority, Proposed Technologies for Mining Deep-seabed Polymetallic Nodules, Proceedings of the ISA's Workshop held in Kingston, Jamaica, (3-6 August 1999) ISA/2001/07 at 34.

${ }^{14}$ UNCLOS, Part XI, Section 4, Article 156.

${ }^{15}$ Id., Article 153(4).

${ }^{16}$ Id., Article 157.

17 D.K. Anton, R.A. Makgill and C.R. Payne, "ITLOS / Case No. 17, Seabed Mining - Advisory Opinion on Responsibility and Liability," Environmental Policy and Law 41, no. 2 (2011): 60-65

18 ISA, Deep Seabed Minerals Contractors, (2018), available online: <https://www.isa.org.jm/deep-seabed-mineralscontractors $>$.
} 
In 2009, the small island state of Nauru asked the ISA to seek an Advisory Opinion, as mandated under Article 191 of UNCLOS, to clarify the liability of sponsoring states. ${ }^{19}$ On February 1, 2011, the Seabed Disputes Chamber (SDC) released its Advisory Opinion on State Liability (Case 17). ${ }^{20}$ This Advisory Opinion is important in several respects, in that it illustrates a number of concepts, principles, and norms, it advances jurisprudence, and it was the first time that NGOs took part in proceedings of the Chamber. ${ }^{21}$ Deepening potential environmental hazards is the issue that State parties are not the only potential sources of environmental damage, as many States do not have the technical nor financial capabilities to undertake DSM. ${ }^{22}$ For example, Nauru admitted that

recognizing this, Nauru's sponsorship of Nauru Ocean Resources Inc. was originally premised on the assumption that Nauru could effectively mitigate (with a high degree of certainty) the potential liabilities or costs arising from its sponsorship. This was important, as these liabilities or costs could, in some responsibilities and obligations of states with respect to 17 activities in the area (advisory opinion of 1 February 2011) circumstances, far exceed the financial capacities of Nauru (as well as those of many other developing States). Unlike terrestrial mining, in which a State generally only risks losing that which it already has (for example, its natural environment), if a developing State can be held liable for activities in the Area, the State may potentially face losing more than it actually has. ${ }^{23}$

Case 17 also clarified certain jurisdictional issues. It clarified that the jurisdiction of the ISA only relates to the exploration and exploitation of minerals from the seabed and lifting them to the surface. ${ }^{24}$ It does not include processing on land or transportation from the high seas superjacent to the Area. ${ }^{25}$ This has impacts on liability and insurability, in that damage occurring in the Area is regulated by the ISA, but as soon as a vessel crossed into another marine area, then other UNCLOS provisions apply. ${ }^{26}$ As will be discussed, this poses liability issues with DSM and potentially necessitates a harmonious relationship with EEZ and territorial water provisions, whether or not these provisions provide adequate environmental protections.

The UNCLOS is vague on the liability standard for States. Case 17 analyzed the "duty to ensure" obligation (i.e., the due diligence obligation) not to cause environmental harm. ${ }^{27}$ The SDC deemed that this due diligence defense obligation is not one of result but of conduct. ${ }^{28}$ It also then implied that this standard would place limits on States' liability, ${ }^{29}$ and the obligation would be met if a State employed, on

\footnotetext{
${ }^{19}$ Anton et al., n. 17 above, p. 61.

${ }^{20}$ Responsibilities and obligations of States sponsoring persons and entities with respect to activities in the Area (Request for Advisory Opinion submitted to the Seabed Disputes Chamber) (ITLOS Case No. 17) (1 February 2011) ITLOS Reports 2011. The SBC was created under UNCLOS, Part XI, s. 5 and Annex VI.

21 A. Dolidze, "Advisory opinion on responsibility and liability for international seabed mining (ITLOS Case 17) and the future of NGO participation in the international legal process," ILSA Journal of International \& Comparative Law 19, no. 2 (2013): 379-418.

22 T. Poisel, "Deep seabed mining: Implications of seabed disputes chamber's advisory opinion," Australian International law Journal 19 (2012): 213-233, p. 215.

${ }^{23}$ Case 17, n. 20 above, para 4.

${ }^{24}$ Id., paras. 94 and 95.

${ }^{25}$ Id., para. 96; see also Anton et al, n. 17 above, p. 62.

${ }^{26}$ Y. Tanaka, "Obligations and liability of sponsoring states concerning activities in the Area: Reflections on the ITLOS advisory opinion of 1 February 2011," Netherlands International Law Review 60, no 2 (2013): 205-230, p. 209.

${ }^{27}$ UNCLOS, Article 139(1). See also Case 17, n. 20 above, para. 108.

${ }^{28}$ I. Plakokefalos, "Seabed disputes chamber of the International Tribunal for the Law of the Sea responsibilities and obligations of states sponsoring persons and entities with respect to activities in the Area," Journal of Environmental Law 24, no. 1 (2011): 133-143, p. 136.

${ }^{29}$ Id., p. 247.
} 
a best-efforts basis, a contractor's compliance. ${ }^{30}$ It also specifically ruled out the application of strict liability against the State. ${ }^{31}$

Question 2 of Case 17 stated: "What is the extent of liability of a State Party for any failure to comply with the provisions of the Convention, in particular Part XI, and the 1994 Agreement, by an entity that it has sponsored under Article 153, paragraph 2(b), of the Convention?" 32 The SDC stated: "In Question 2, the English term "liability" refers to the consequences of a breach of the sponsoring State's obligations." 33 Anton notes that it is customary in international law to first look at the private contractor for compensation of harm caused by a wrongful act, even if attributed to the State. ${ }^{34}$ It is only if total compensation is not achieved that residual liability to the State might be applied. ${ }^{35}$ There is thus a major gap, should serious environmental damage take place. Moreover, the court did not address several major issues, as will be discussed later. Specifically, the court noted, "Considering that the potential for damage, particularly to the marine environment, may increase during the exploitation phase, it is to be expected that member States of the Authority will further deal with the issue of liability in future regulations on exploitation. The Chamber would like to emphasize that it does not consider itself to be called upon to lay down such future rules on liability." 36

Substantial developments have taken place since Case 17 was released. Two main developments that require the speedier development of liability regulations include new scientific discoveries and the rapid development of technologies which are making commercial exploitation of the Area feasible. Scientific uncertainty in the Area and the need to apply the Precautionary Approach to DSM cannot be overstated. For example, in 2015, a group of researchers from the University of Rhode Island discovered large numbers of egg cases adjacent to hydrothermal vents off the coast of the Galapagos Islands. ${ }^{37}$ This was the first case of this type of behaviour among a marine animal recovered. These vents are the same vents thought to hold massive amounts of mineral deposits, and are soon to be explored in the DSB, providing evidence that exploration of the Area's DSB could have a material impact on the marine living environment. ${ }^{38}$ As will be discussed, the types of mining will vary according to the type of mineral in the Area. As such, a range of differing toxic metal mixtures may be released into the sea. This has been shown to disrupt an organism's cell structure, at least in the territorial waters area. ${ }^{39}$ Scientists do not yet know if the effects on land or shallow waters apply to the DSB, and many urge the use of the "weight of evidence approach" and a more scientifically based environmental assessment process, as there are still too many unknowns as it relates to the DSB. ${ }^{40}$ These are just two small examples of the scientific uncertainty surrounding the Area, should environmental damage occur.

However, time is running out for this weight of evidence approach to be more fully developed, as there are now technologies available that can mine at depths below $1.5 \mathrm{~km}$. The first commercial

\footnotetext{
${ }^{30}$ Case 17, n. 20 above, para. 110.

${ }^{31}$ Id., para. 189.

32 Id., para. 164.

33 Id., para. 70.

34 D.K. Anton, "The principle of residual liability in the seabed disputes chamber of the International Tribunal for the Law of the Sea: The advisory opinion on responsibility and liability for international seabed mining (ITLOS Case No. 17)," McGill International Journal of Sustainable Development Law and Policy 7, (2012): 241-257, p. 249; see also G. Doeker and T. Gehring, "Private or international liability for transnational environmental damage: The precedent of conventional liability regimes," Journal of Environmental Law 2, no. 1 (1990): 1-16 and International Law Commission, n. 8 above, paras. 340-386.

${ }^{35}$ Id., p. 247.

${ }^{36}$ Case 17, n 20 above, para. 168.

37 P. Salinas-de-León et al., "Deep-sea hydrothermal vents as natural egg-case incubators at the Galapagos Rift," Scientific Reports, 8:1788 (2018): 1-7, available online: <https:/www.nature.com/articles/s41598-018-20046-4>

${ }^{38}$ Id., p. 5.

${ }^{39}$ C. Hauton et al., "Identifying toxic impacts of metals potentially released during deep sea mining: A synthesis of the challenges and quantifying risk," Frontiers of Marine Science 4:368 (2017): 1-13, p. 9.

${ }^{40}$ Id., p. 12.
} 
operation of DSM will take place off the coast of Papua New Guinea ("PNG") in 2019, if financial hurdles are overcome. ${ }^{41}$ At approximately $35 \mathrm{~km}$ from $\mathrm{PNG}$, and sitting at a depth of 1,600 $\mathrm{m}$, the Solwara 1 project will use innovative mining techniques to extract copper, with some gold deposits having potential commercial significance. ${ }^{42}$ Although the project will take place in the EEZ of PNG, the depth of the drilling and type of extraction shows similarities to other DSM in the Area. Additionally, as will be described below, PNG has partnered with Nautilus Minerals Inc. (Nautilus), a Canadian company listed on the Toronto Stock Exchange, ${ }^{43}$ to be the Contractor. ${ }^{44}$ As is the case with Tonga and Nauru in the Area, PNG does not have the financial, or the technical resources, to conduct DSM on its own. ${ }^{45}$ Nautilus does not own the vessel, but has chartered the vessel from Dubai-based Marine Assets Corporation. ${ }^{46}$ This highlights a fourth party that could have liability - that is the "flag State" vessel. ${ }^{47}$ Solwara 1 is also important as Nautilus also owns a valued license in the Clarion Clipperton Zone $(\mathrm{CCZ}){ }^{48}$ The results of Solwara 1 and any environmental damage from the mining may have a profound influence on the development of extraction in the Area. ${ }^{49}$ The type and quantum of damage in the EEZ, and the resulting liabilities to the parties would provide meaningful data applicable to the Area. ${ }^{50}$ Further research is required.

In 2011, Tonga Offshore Mining Limited (TOML), a sponsored company of the Tonga government, but owned by Nautilus Minerals, was granted approximately 75,000 sq. $\mathrm{km}$ in the highly prospective CCZ. ${ }^{51}$ The CCZ has been identified by the ISA as a zone of particular importance, especially

41 Mining Watch Canada, "Nautilus AGM: Solwara 1 Deep Sea Mining Venture Remains a Speculative Pipe Dream," Press Release (28 June 2017), available online: <https://miningwatch.ca/news/2017/6/28/nautilus-agmsolwara-1-deep-sea-mining-venture-remains-speculative-pipe-dream $>$. See also, Deep Sea Mining Campaign, Former Attorney General of Papua New Guinea: The writing is on the wall for Solwara 1 - PNG should withdraw its investment before it's too late (17 January 2018), Media Release. However, according to its own disclosures, a Q3 2019 is still targeted. See Nautilus Minerals Inc., Material Change Report 51-102F1 (28 February 2018) accessed via SEDAR.

${ }^{42}$ K. Gena, "Deep sea mining of submarine hydrothermal deposits and its possible environmental impact in Manus Bas in, Papua New Guinea," Procedia Earth and Planetary Science 6 (2013): 226-233, p. 230.

${ }^{43}$ Nautilus Minerals is a Canadian mining company listed on the TSX, ticker symbol "NUS." Having only a market capitalization of approximately CA $\$ 127$ million and a negative revenue stream at the time of writing, there is a real risk of the project having serious financial issues, which would indicate that any environmental damage would have serious financial repercussions. For a video depicting the vessel to be used and the mining techniques employed, see $<$ http://www.nautilusminerals.com/irm/content/video-gallery.aspx? RID=421 $>$.

44 “Nautilus Minerals Receives World's First Deep-Sea Mining Lease for Solwara 1," Sea Technology 52:3 (2011): 49.

${ }^{45}$ H. Rosenbaum, Out of our depth: Mining the ocean floor in Papua New Guinea . (online: Mining Watch Canada, 2011). available online: http://www.deepseaminingoutofourdepth.org/wp-content/uploads/Out-Of-Our-Depth-lowres.pdf

46 M. Schuler, "First Deep Sea Mining Production Vessel Launched in China," (30 March 2018) Press Release, available online: <http:/gcaptain.com/first-deep-s ea-mining-production-vessel-launched-in-china/>.

${ }^{47}$ The Flag State of this vessel is still unclear. This vessel was built in China by Fujian Mawei shipbuilding, and the basic design for the seabed mining vessel is provided by SeaTech Solutions International, a marine designs specialist based in Singapore. The takeaway is the number of parties involved and issues of liability (which design flaw, construction problem, or maintenance issue) are all to be determined. There are still many financial issues with this project. See Material Change Report, BCSC Form 51-102F3, Nautilus Minerals Inc., (18 December 2017).

${ }^{48}$ As a TSX-listed issuer, NUS is mandated to provide securities laws disclosures. See Technical Report, TOML Clarion Clipperton Zone Project, Pacific Ocean), (27 February 2018), made pursuant to Standards of Disclosure for Mineral Projects, BCSC NI 43-101 (9 May 2016).

${ }^{49}$ Nautilus Minerals Niugini Limited, Environmental impact statement: Solwara 1 Project (2008) available online: $<\mathrm{http}: / / \mathrm{www} . n a u t i l u s m i n e r a l s . c o m / \mathrm{irm} /$ content/pdf/environment-reports/EnvironmentalImpactStatementMain

Report.pdf>.

${ }^{50}$ Technical Report, n. 48 above.

51 P. Taumoepeau, "Re: Developing a Regulatory Framework for Mineral Exploitation in the Area - Report to Members of the Authority and all Stakeholders," Letter to ISA from Tonga Offshore Mining Limited, (25 May 2015) 
from an environmental perspective. ${ }^{52}$ From a DSM perspective, the CCZ is an area particularly rich in polymetallic nodules. ${ }^{53}$ From an environmental perspective, it is also of significance. As such, in July, 2012, the ISA adopted an Environmental Management Plan for the CCZ. ${ }^{54}$ This Plan has a provision for an EA but no additional liability provisions. ${ }^{55}$ Given the decision in Case 17, that due diligence standards may differ depending on the type of mining, it is imperative to have higher standards for environmental liabilities in the CCZ.

\section{PART 2 - CURRENT STATE OF EA AND MINING REGULATION IN THE AREA}

Given the historical context discussed above, it is necessary to investigate the current state of regulation in the Area. Article 145 of the UNCLOS contains basic environmental protection requirements, stating that the ISA shall adopt rules regulations and procedures for the prevention, reduction, and control of pollution and other hazards to the marine environment, including the ecological balance and the protection of flora and fauna. ${ }^{56}$ Article 139 of the UNCLOS sets out basic liability requirements for the Area. ${ }^{57}$ Article 139(2) notes that damage caused by the failure of a State Party or international organization to carry out its responsibilities "shall entail liability" [emphasis added]. ${ }^{58}$ This liability is joint and several between the State and the Contractor. However, a State is not liable for damage caused by any failure of the Contractor to comply if the State has taken "all necessary and appropriate measures" [emphasis added] to secure effective compliance under Article 153(4), and Annex III(4)(4). ${ }^{59}$ This carve-out provision is contained in Annex III, Article 4(4), stating that the Sponsoring State shall ensure that the Contractor shall carry out its activities according to the contract and the UNCLOS. However, the Sponsoring State is not [emphasis added] liable due to damage caused by any failure of a contractor, sponsored by the State, to comply with its obligations if that State Party has adopted laws and regulations and taken administrative measures which are, within the framework of its legal system, reasonably appropriate for securing compliance by persons under its jurisdiction. ${ }^{60}$ Article 209 requires States to adopt laws and regulations to prevent, reduce, and control pollution coming from activities in the Area - laws which shall be no less effective than the international rules. ${ }^{61}$ Furthermore, section 235 necessitates domestic legislation for compensation or other relief of damage caused by pollution of the marine environment. ${ }^{62}$ Finally, Annex III, Article 22, states that the contractor shall have liability arising out of wrongful acts [emphasis added] in the conduct of its operations. ${ }^{63}$ The ISA itself can be liable under the same provision, in that the ISA shall be liable for any damage arising out of wrongful acts in the exercise of its powers and functions. ${ }^{64}$

(Jamaica: ISA, available online: $<$ https://www.isa.org.jm/sites/default/files/toml_0.pdf $>$. See also ISA contract, (11 January 2012) between TOML and ISA.

52 ISA, Legal and Technical Commission, Rationale, and recommendations for the establishment of preservation reference areas for nodule mining in the Clarion-Clipperton Zone ISBA/14/LTC/2* (28 March 2008).

${ }^{53}$ ISA, A geological model of polymetallic nodule deposits in the Clarion-Clipperton fracture zone (ISA Technical Study no. 6) (Kingston, Jamaica: International Seabed Authority, 2010).

54 ISA, Decision of the Council relating to an environmental management plan for the Clarion-Clipperton Zone, ISBA/18/C/22 (26 July 2012).

${ }^{55}$ ISA, Environmental Management Plan for the Clarion-Clipperton Zone, ISBA/17/ LTC/7 (13 July, 2011).

${ }^{56}$ UNCLOS, n. 1 above, Article 145.

${ }^{57}$ Id., Article 139.

${ }^{58}$ Id., Article 139(2)

${ }^{59}$ Id., Article 139(2).

${ }^{60} 1994$ Agreement, Annex III, Article 4, para. 4.

${ }^{61}$ UNCLOS, n. 1 above, Article 209(2) this is the bas is of flag State liability.

${ }^{62}$ Id., Article 235(2).

${ }^{63}$ Id., Annex III, Article 22.

${ }^{64}$ Id. 
The language used in the UNCLOS seems to be conflicting. In Article 139(2), the sponsoring state escapes liability only if "all necessary and appropriate measures" have been taken ${ }^{65}$ Yet, Annex III merely requires adoption of laws that are "reasonably appropriate for securing compliance." UNCLOS, there is a weakening of liability for Sponsoring States. However, Case 17 did not address all issues of liability. To this end, the ISA has developed regulations that are the primary means by which the ISA develops procedures and rules around all aspects of DSM. ${ }^{67}$ Relevant to this article are the Mining Code, article 165(5) recommendations, and the Draft Regulations.

The Mining Code is the collection of the regulations adopted by the ISA. ${ }^{68}$ The ISA, to date, has recommended and adopted three sets of regulations dealing with DSM. They are: Regulations on Prospecting and Exploration for Polymetallic Nodules in the Area (Nodules Regs) $;{ }^{69}$ Regulations on Prospecting and Exploration for Polymetallic Sulphides in the Area (Sulphides Regs) ${ }^{70}$ and Regulations on Prospecting and Exploration for Cobalt-rich Ferromanganese Crusts in the Area (Cobalt Crusts Regs). ${ }^{71}$ These regulations are designed to apply to the exploration and prospecting of the Area, and directly apply to exploitation of Resources. ${ }^{72}$ As noted in Case 17 , there may be a different due diligence requirement for each of the types of mining, ${ }^{73}$ yet the drafting of each of the regulations is similar. Thus, there may be a gap between the decision of Case 17 and the regulatory standards required under the Code.

Throughout the Mining Code, the protection of the environment is noted as important. ${ }^{74}$ In the Nodules Regs, Regulation 2 states that Prospectors and the Authority shall use the Precautionary Approach. ${ }^{75}$ Regulation 2(3) of the Cobalt Crusts Regs states that prospecting shall not be undertaken if substantial evidence indicates the risk of serious harm to the marine environment. ${ }^{76}$ It is worth noting that while the Sulphides Regs provide the obligation to apply "best environmental practices" for the sponsoring State, there is no similar reference in the earlier Nodules Regs. ${ }^{77}$ Regulation 30 of the Nodules Regs states that responsibility and liability of the contractor and of the authority shall be in accordance

${ }^{65}$ Id. Article 139(2)

${ }^{66}$ Id., Annex III

67 A. Jaeckel, "Deep sea bed mining and adaptive management: The procedural challenges for the International Seabed Authority," Marine Policy 70 (2016): 205-211, p. 207.

${ }^{68}$ ISA, Mining Code, available online: <https://www.isa.org.jm/mining-code>. The Mining Code of the ISA is the set of rules regulations and procedures issued by the ISA to regulate the prospecting exploration and exploitation of marine minerals in the Area.

${ }^{69}$ ISA, Regulations on Prospecting and Exploration for Polymetallic Nodules in the Area, ISBA/6/A/18 (13 July 2000), amended by ISBA/ 19/A/9; ISBA/19/A/12 (25 July 2013) and ISBA/20/A/9 (24 July 2014). Nodules include manganese, cobalt, copper, and nickel.

${ }^{70}$ ISA, Regulations on Prospecting and Exploration for Polymetallic Sulphides in the Area, ISBA/16/A/12/Rev.1 (15 November 2010), amended by ISBA/19/A/12 (25 July 2013) and ISBA/20/A/10 (24 July 2014). Polymetallic sulphides means hydrothermally formed deposits of sulphides and accompanying mineral resources in the Area which contain concentrations of metals including, inter alia, copper, lead, zinc, gold and silver.

71 ISA, Regulations on Prospecting and Exploration for Cobalt-rich Ferromanganese Crusts in the Area, ISBA/18/A/11 (27 July 2012), amended by ISBA/19/A/12 (25 July 2013). The definition of cobalt-rich ferromanganese crusts includes: cobalt-rich iron/manganese (ferromanganese) hydroxide/oxide deposits formed from direct precipitation of minerals from seawater onto hard substrates containing minor but significant concentrations of cobalt, titanium, nickel, platinum, molybdenum, tellurium, cerium, other metallic and rare earth elements.

${ }^{72}$ Id., Preamble.

${ }^{73}$ Case 17, n. 20 above, para. 136 for best environmental practices, para. 142 for EA and due diligence, para. 154 for developing States and due diligence and para. 242, the ruling.

${ }^{74}$ E. Van Doorn, "Environmental aspects of the mining code: Preserving humankind's common heritage while opening Pardo's box?," Marine Policy 70 (2016): 192-197, p. 195.

${ }_{76}^{75}$ Nodules Regs, n. 69 above, Regulation 2.

${ }^{76}$ Cobalt Crusts Regs., n. 71 above, s. 2(3).

77 J. Gao, "The responsibilities and obligations of the sponsoring states advisory opinion," Chinese Journal of International Law 12 (2013): 771-786, p. 775. 
with the UNCLOS. ${ }^{78}$ The contractor shall continue to have responsibility for any damage arising out of "wrongful acts in the conduct of its operations" [emphasis added], in particular damage to the marine environment, after the completion of the exploration phase. ${ }^{79}$ The key section here is "damage arising out of wrongful acts in the conduct of its operations." ${ }^{80}$ This would seem to preclude any strict liability, and even the due diligence threshold may not be applicable. Yet there is no guidance on how this could be interpreted.

Given an estimated minimum USD 1 billion capital cost to develop a nodule processing plant, ${ }^{81}$ and the potential for these minerals to be used in a long-term strategic procurement initiative, ${ }^{82}$ the lack of more stringent liability provisions is problematic. Some of the issues are thought to be dealt with via contract law. ${ }^{83}$ For example, the Cobalt Crusts Regs Annex IV Standard clauses for exploration contract provides for liability in contractual terms. ${ }^{84}$

Complementing the Mining Code are the Recommendations. Under Article 165(2) of the UNCLOS, the ISA Legal and Technical Commission may make recommendations on the protection of the marine environment. ${ }^{85}$ On March 1, 2013, the LTC released its recommendations for the guidance of contractors for the assessment of the possible environmental impacts arising from exploration for marine minerals in the Area ("Recommendations"). ${ }^{86}$ Under the guise of the Precautionary Approach, the Recommendations state that every plan of work for exploration for marine minerals shall take into consideration the following phases of environmental studies: (a) Environmental baseline studies; (b) Monitoring to ensure that no serious harm is caused to the marine environment from activities during prospecting and exploration; and (c) Monitoring during and after testing of collecting systems and equipment. ${ }^{87}$ Unfortunately, liability guidelines are silent in the recommendations. ${ }^{88}$ Moreover, these recommendations deal only with exploration and prospecting, not commercial activity where most of the environmental damage is thought to occur.

On August 8, 2017, the ISA released its Draft Regulations on Exploitation of Mineral Resources in the Area, (Draft Regulations) ${ }^{89}$ with an explanatory note from the Secretariat on August 10, $2017 .^{90}$

${ }_{78}$ Cobalt Crusts Regs, n. 66 above, s. 32.
${ }^{79}$ Nodules Regs, n. 69 above, Regulation 30.
${ }^{80}$ Id.
${ }^{81}$ E. Egede, "African states and participation in deep seabed mining: Problems and prospects," The International Journal of Marine and Coastal Law 24 (2009): 683-712, p. 685. Given the age of this article, it would be likely even more expensive to build. These costs cannot be ignored relative to developing nations and the "common heritage of mankind' doctrine, as it will most likely entail large transnational corporations or large state owned enterprises that become the Contractors.

${ }^{82}$ Id., p. 700.

${ }^{83}$ For example, in the responses to the Draft Regulations, several countries argue that terms should be defined in the contracts section, not in the regulations.

${ }^{84}$ Cobalt Crusts Regs, n. 71 above, Annex IV.

${ }^{85}$ UNCLOS, Article 165(2).

86 ISA, Recommendations for the guidance of contractors for the assessment of the possible environmental impacts rising from exploration for marine minerals in the Area, International Seabed Authority ISBA/19/LTC/8 (1 March 2013).

${ }^{87}$ Id., para. 11 .

88 The Legal and Technical Commission during their March and July 2018 meetings will begin to investigate guidelines to complement the Draft Regulations.

${ }^{89}$ ISA, Draft Regulations on Exploitation of Mineral Resources in the Area, (8 August 2017) ISBA/23/LTC/CRP.3.

${ }^{90}$ ISA, Draft regulations on exploitation of mineral resources in the Area, Note by the Secretariat, (10 August 2017) ISBA/23/C/12 Unfortunately, due diligence and other liability issues were mostly ignored. For example, question 2 , of the Note states: "Contract area: for areas within a contract area not identified as mining areas, what due diligence obligations should be placed on a contractor as regards continued exploration activities? Such obligations could include a programme of activities covering environmental, technical, economic studies or reporting obligations (that is, activities and undertakings similar to those under an exploration contract). Are the concepts and definitions of "contract area" and "mining area(s)" clearly presented in the draft regulations?" 
The Draft Regulations contain a comprehensive set of environmental assessment provisions. ${ }^{91}$ These regulations, unfortunately, fall far short of implementing a full liability regime for environmental harms. The Draft Regulations contain provisions for the application process, environmental impact assessment, and Performance Guarantees. ${ }^{92}$ Annex V contains the Environmental Impact Statement Template. ${ }^{93}$

The liability provisions are contained in Annex X, Section 8, which states:

8.1 The Contractor shall be liable to the Authority for the actual amount of any damage, including damage to the Marine Environment, arising out of its wrongful acts or omissions, [emphasis added] and those of its employees, subcontractors, agents and all persons engaged in working or acting for them in the conduct of its operations under this Contract, including the costs of reasonable measures to prevent, limit, and ameliorate damage to the Marine Environment, account being taken of any contributory acts or omissions by the Authority or third parties. This clause survives the termination of the Contract and applies to all damage caused by the Contractor regardless of whether it is caused or arises before, during, or after the completion of the Exploitation Activities or Contract term. ${ }^{94}$

This is an important term in the contract, and seems to contradict Article 139 and Case 17. It provide s that the liability is to the ISA, and not any one government, and survives the end of the Contract. It also provides for damages being the actual amount of damages, so it does not appear that damage claims will be limited. Also, as previously noted, the ISA is a party with potential liability over damage to the marine environment. Draft Regulation 8.2 provides for an indemnity to the ISA stating:

8.2 The Contractor shall indemnify the Authority [emphasis added], its employees, subcontractors and agents against all claims and liabilities of any third party arising out of any wrongful acts or omissions of the Contractor and its employees, agents and subcontractors, and all persons engaged in working or acting for them in the conduct of its operations under this Contract. $^{95}$

Of clear note, both Draft Regulation 8 and the Draft Contract only call for damages related to "wrongful acts or omissions ",96 [emphasis added]. There are no strict liability or negligence provisions; as such, these regulations are incomplete. It is unclear about due diligence or mens rea requirements. It is also unclear whether other compensatory or punitive damage claims could be advanced, as it states "actual amount of damage." 97 It provides additional evidence that the ISA is a party and could potentially be liable for environmental harms. Unfortunately, this indemnification is vague on details.

Annex X of the Draft Regulations contains the Standard Clauses for exploitation contract. ${ }^{98}$ Like most contracts, its focus is on the rights and titles to the minerals, and it is, unfortunately, very brief and vague on environmental liabilities. ${ }^{99}$ Under section $3.2(\mathrm{~d})$, the contractor must file an environmental management and monitoring plan; ${ }^{100}$ and under section 3.3, the contractor shall carry out its obligations under this contract with "due diligence, efficiency, and economy, with due regard to the effect of its activities on the marine environment, and exercising reasonable regard for other activities in the marine

\footnotetext{
${ }^{91}$ See Annex I below for Draft Regulations relating to environmental protections

92 Draft Regulations, n. 89 above, Regulation 9.

93 Id., Annex V.

${ }^{94}$ Id., Annex $X-$ Section 8.1.

${ }^{95}$ Id., Section 8.2.

96 Id., Section 8.

${ }^{97}$ Id. Section 8.3

98 Id., Annex I.

${ }^{99}$ Some would argue that liability will be contractually based rather than regulatory based.

${ }^{100}$ Draft Regulations, n. 89 above, s. 3.2(d).
} 
environment." ${ }^{101}$ Potentially, this plan of work and contractual obligations could satisfy the due diligence defense, if applicable.

In January 2017, prior to the release of the initial Draft Regulations, the ISA released a working paper on environmental matters. ${ }^{102}$ The paper draws upon the experience from land-based mining and oil and gas regimes, the shipping industry, and deep-sea fishing activities. ${ }^{103}$ One clear recommendation is on the creation of the "Environmental Liability Trust Fund." 104 The initial draft of the Draft Regulations also contained a substantive provision for a financial guarantee or security that would assist in liability claims and would help offset the costs of environmental remediation. ${ }^{105}$ The published Draft Regulations have been watered down, creating instead a "Performance Guarantee" provision which is much less robust. ${ }^{106}$ The published Draft Regulations do not mention any trust, technology, or environmental liability fund. Thus, the watered-down regulations either do not address gaps in liabilities or they create them.

Stakeholder submissions to the Draft Regulations were released in January, 2018. ${ }^{107}$ Of note was Australia's response, which will be detailed below. ${ }^{108}$ However, there is still much discussion and disagreement in the international community on the Draft Regulations, environmental protections, and the gaps in environmental liabilities. The ISA has stated its goal of having the Draft Regulations adopted by $2020,{ }^{109}$ so time is of the essence.

On September 28 and 29, 2017, a legal working group convened to develop a work plan to carry out further research. ${ }^{110}$ After a review of current UNCLOS and domestic legislation, the working group noted several issues. These involved liability in context of "effective control" and the role of sponsoring states, key sources of risks, potential failure of sea-floor tools, including the production vessel itself, collisions, and the potential roles of environmental funds, bonds, and insurance. ${ }^{111}$ Arising out of the conference came six bundles of issues: the purpose and scope of the regime, channeling liability/effective control, actionable damage, procedures, standards of liability, and form of the regime. ${ }^{112}$ This article will address several of these issues.

${ }^{101}$ Id., s. 3.3.

102 ISA, Developing a Regulatory Framework for Mineral Exploitation in the Area: A Discussion Paper on the development and drafting of Regulations on Exploitation for Mineral Resources in the Area (Working Paper, Environmental Matters) (Jamaica: ISA, 2017).

${ }^{103}$ Id., para. 4.2 .

104 Id., s. II, Possible working structure for the "Environmental Regulations" Part XII Compensatory measures, Section 1. This provision also called for the creation of a Seabed Mining Sustainability Fund - Draft Regulation 69

105 Id., Draft Regulation 44 Provision for a Financial Guarantee or Security.

${ }^{106}$ Draft Regulations, n. 89 above, Regulation 9.

107 ISA, Submissions to International Seabed Authority's Draft Regulations on Exploitation of Mineral Resources in the Area, ISBA/23/C/12 ISBA/23/LTC/CRP.3 (10 January 2018) Stakeholder submissions on the draft regulations have only been released in early 2018. See:

$<\mathrm{https}$ ://www.isa.org.jm/news/international-s eabed-authority-releas es-stakeholder-submis sions-draft-exploitationregulations $>$.

${ }^{108}$ Australia, Government of Australia's submission on the draft Regulations on Exploitation of Mineral Resources in the Area (20 December 2017) ISBA/23/C/12.

109 Pew Charitable Trusts, Summaries of Stakeholder Submissions on the ISA Draft Exploitation Regulations, Second report of the Code Project, White Paper, (1 March 2018) available online: $<$ http://www.pewtrusts .org/en/res earch-and-analys is/white-papers/2018/03/summaries -of-stakeholder-submis sions on-the-isa-draft-exploitation-regulations $>$.

110 F.-K. Phillips, Conference Report, London, United Kingdom, September 2017, Legal Working Group on Liability for Environmental Harm from Activities in the Area, (Waterloo: Centre for International Governance Innovation, 2018) p. 2.

111 Id., p. 5.

${ }^{112}$ Id., pp. 9-10. 
From March 5 to 8, 2018, the ISA convened Part I the 24th Session of the ISA (the Session), with the goal of having the next round of draft regulations available in July, 2018. ${ }^{113}$ Day 1 of the Session outlined the purpose of the meeting, and, for purposes of this article, there are several important discussion points, including: the role of the sponsoring state, the role of legal status of standards and LTC guidelines, the broader environmental policy and regulations on exploitation, and the roles of the ISA. ${ }^{114}$ The ISA noted that compliance of contractors was not a pressing issue due to the preliminary nature of the work, but now that prototyping and full operation is near, compliance will become important. ${ }^{115}$ Day 3 featured consideration of the role of sponsoring states, the ISA and contractors, including questions of liability, and the role and legal status of standards, recommendations and guidelines. ${ }^{116}$ There are also discussions on the legally binding nature of the ISA rules and guidelines. ${ }^{117}$

Part 1 of the Session did not provide consensus to any gaps in liabilities. Rather, it seemed to ask more questions than it answered. The ISA will defer to the LTC to discuss more technical provisions of the Draft Regulations. As such, from March 12 to 23, 2018, the LTC of the ISA will be meeting, with Part 2 of the Session of the ISA to take place in July, 2018. Whether or not additional question will be addressed remains to be seen.

Given that many nations cannot yet agree on compliance and liability for the Area, it is more important that academia provide guidance. Thus, the current state of the law of DSM should be compared with other environmental assessment and liability laws in other marine contexts. ${ }^{118}$ To first compare with other regimes, a gap analysis of the current law must be undertaken.

\section{Gap Analys is}

One of the gaps in knowledge is the type of mining that would be conducted on the seabed. One type of mining would involve drilling into the seabed, similar to conventional oil drilling onshore. A second type of mining would be a marine equivalent to "open pit" mining - that is, the extraction of minerals over a wide area of the sea floor. ${ }^{119}$ As noted in Case 17, the type of mining will change the nature of due diligence obligations, and even strict liability and damage claims may be altered. Thus, the Draft Regulations need to address each type of mining with specific EA provisions, as the exploration regulations have done.

A second gap in knowledge is scientific uncertainty, as the majority of the seafloor is unexplored. ${ }^{120}$ Any extraction or even exploration could have a material negative impact on unknown biota to the unknown extent, duration, and toxicity of plumes. ${ }^{121}$ If the scientific community does not yet know what types of living species are on the DSB, it is unclear as to how standards of conduct can be drafted to deal with the types of harm that could occur. A precautionary approach and even a moratorium on drilling would be for scientific advances to take place and provide for more evidence.

\footnotetext{
113 ISA, 1st Part of the 24th Session of the International Seabed Authority 5-9 March 2018, Headquarters of the International Seabed Authority, Kingston, Jamaica Day 1 (ISA 24th Session, Day 1).

114 Earth Negotiations Bulletin, "Summary of the Twenty Fourth Annual session of the International Seabed Authority (First Part)," Press Release (9 March 2018) 25:157.

115 OceansLaw, "Rule of Law Committee for the Oceans, LOS News - 6 March 2018: the ISA and Seabed Mining Code - Day 1 Report," (6 March 2018) Oceanlaw.org.

${ }^{116}$ ISA 24th Session, n. 113 above, Day 3 report.

117 Id., Day 3 Report.

118 They should also be compared with onshore extractive industries; however, this is beyond the scope of this article.

119 KA. Miller et al., "An overview of seabed mining including the current state of development, environmental impacts, and knowledge gaps,” Frontiers in Marine Science 4 (2018), online: DOI: 10.3389/fmars.2017.00418. $120 \mathrm{Id}$.

121 K. Gjerde, “The ISA's Biggest Issue of 2018,” Press Release, DSM Observer (4 March 2018), available online: $<\mathrm{http}: / / \mathrm{dsmobs}$ erver.org/2018/03/is as -biggest-is sue-2018/>.
} 
Many scholars view that on-shore and near off-shore extraction poses more harms than DSM. ${ }^{122}$ A third unknown is the lack of knowledge on the extent of environmental and compensable damage that may occur from DSM. Thus, any negligence or liability claim may not have the sufficient legal grounds to warrant a finding of guilt on the contractor or sponsoring state. While Article 139 of the UNCLOS creates a liability regime, the Annexes and Draft Regulations speak about a "wrongful act or omission" threshold. ${ }^{123}$ There is no strict liability or negligence argument contained in the Draft Regulations. ${ }^{124}$ Moreover, the Environmental Management Plan does not contain any requirement to have insurance or financing in place for any environmental damage. ${ }^{125}$ The Draft Regulations are vague in their assessment of liabilities for environmental damage. The issues of remoteness and other legal definitions, such as "wrongful acts," are neither defined nor explained.

As noted above, and to this end, a strong response to the Draft Regulations came from the Australian delegation. Australia submits that it

is of the view that there needs to be more detail regarding the liability of a sponsoring state and how it can take responsibility for ensuring exploitation is undertaken in a safe and environmentally responsible manner. For example, the liability and enforcement mechanisms in the Regulations need to act as an effective deterrent to prevent Contractors from causing environmental harm or violating safety regulations. Australia suggests that, in addition to the monetary penalties prescribed in Appendix III of the Draft Regulations, consideration should be given to the application of monetary penalties for a broader range of breaches of environmental regulations, such as the failure to adhere to the Environmental and Management Monitoring Plan. $^{126}$

The questions addressed in Case 17 are limited in scope and do not provide for a fulsome answer. The SDC also notes that one consequence of the exclusion of water evacuation and disposal of material from "activities in the Area" would be that the activities conducted by the contractor which are among the most hazardous to the environment would be excluded from those to which the responsibilities of the sponsoring State apply. ${ }^{127}$ Case 17 did not address liability provisions of the flag State.

A fourth gap, therefore, includes the roles of the flag State and the vessel State (and potentially the processing State) for responsibility and liability. It is the responsibility of the Authority to determine both the rate at which exploitation of the Area will be allowed, and the methods in which the proceeds from exploitation will be shared among the members of the international community, as well as between current and future generations. ${ }^{128}$ African countries could very much, through a subsidiary of a transnational corporation, sponsor their way into DSM, as small island states have done. ${ }^{129}$ Developing countries often has weak environmental protection legislation. ${ }^{130}$ The lack of domestic DSM legislation in

122 L.D. Bulong, "Into the abyss: Rationalizing commercial deep seabed mining through pragmatism and international law," Tulane Journal of International and Comparative Law 25 (2016): 128-181, p. 175.

${ }^{123}$ UNCLOS, Article 139, and Draft Regulations, para. 8.2.

124 See also Case 17, n. 20 above, para. 179.

125 Draft Regulations, n 89 above, Regulation 19.

126 Government of Australia, Government of Australia's submission on the draft Regulations on Exploitation of Mineral Resources in the Area, received 20 December 2017, available online: $<$ https://www.isa.org.jm/files/documents/EN/Regs/2017/MS/Australia.pdf>. A complete list of submissions was released. See ISA, Submissions to International Seabed Authority's Draft Regulations on Exploitation of Mineral Resources in the Area (ISBA/23/C/12; ISBA/23/LTC/CRP.3*) (date, 2017) Available online: $<\mathrm{https}$ ://www.isa.org.jm/files/documents/EN/Regs/2017/List-1.pdf>.

${ }^{127}$ Case 17, n. 20 above, para 97.

1281994 Agreement, Annex, Sec. (6).

129 Egede, n. 81 above, p. 697.

${ }^{130}$ Id., p. 698, this statement would apply not only to African states, but any state that lacks capacity or willingness to provide for vigorous flag registration requirements. 
these jurisdictions is problematic, as there is no domestic environmental legislation to backstop a damage claim. But, more importantly, the legislation below creates indemnification provisions for these States. How States will be indemnified is still unknown. The most likely source will be in DSM insurance. The Interoceanmetal Joint Organisation highlighted this fact in their response to the Draft Regulations, stating:

it should be carefully analyzed because actual suspension of mining operations in the Area, taking into account the risks associated, predicted structure of the operational costs and cash flow regime may very likely result in the real life in the mining termination with little chances for recovering the production and all risks associated are included, including environmental....Insurance cost should be recognized for the proper considerations of contractor's economic models ongoing now in the Authority. Probably, common insurance conditions valid for all contracts should be proposed in further regulations. It is not clear if there is now market for such kind of insurance. ${ }^{13}$

More information and clarification on the role of financing and insurance is required, especially as the SDC ruled out residual liability. ${ }^{132}$

Finally, the issue of which parties can bring claims is still unresolved. ${ }^{133}$ Not only are sponsoring states and the ISA potential defendants, they are also potential claimants. In summation, there is still much uncertainty over the provision requiring domestic legislation. The References are made to Sponsoring States in the working draft, but the lines of duty and responsibility (jurisdictional competence) between the Authority and sponsoring States (together with that of flag States, States Parties, and nonParties to the Convention and relevant international organizations, including the International Maritime Organization) are not entirely clear. ${ }^{134}$ For example, Australia “welcomed references to sponsoring states' national legislation, noting that the system should also help contractors decide which sponsoring state to approach." ${ }^{135}$ Belgium stressed the need for: "a balanced relationship between the ISA and contractors; clarity on monitoring rules to avoid "sponsor shopping"; and more attention to environmental regulations." 136 China on the other hand, "arguing that sponsoring states that have taken necessary and appropriate measures should not be held responsible for contractors' misconduct." ${ }^{137}$ There is thus serious disagreement over liability and obligations. ${ }^{138}$

\section{PART 3 - STATE OF NATIONAL LEGISLATION OF DSM}

\footnotetext{
131 Interoceanmetal Joint Organization, Comments provided by the Interoceanmetal Joint Organization IOM to the document "Draft regulations on exploitation of mineral resources in the Area" (22 November 2017) ISBA/23/C/12; ISBA/23/LTC/CRP.3*.

132 Case 17, n. 20 above, para. 204.

133 Id., paras. 179 and 180.

${ }^{134}$ Working Paper, Environmental Matters, n. 102 above, para. 4.6.

135 Australia Response, n. 126 above.

136 ENB, "Response by Belgium ISA during 24th Sessions," ISA-24 Part 1 Highlights, $25: 155$ (7 March 2018 ), available online: <http://enb.iisd.org/vol25/enb25155e.html>. See also Belgium, "Concerns: Comments on the draft regulations on exploitation of mineral resources in the Area," (20 December 2017), Response to ISA Draft Regulations, ISBA/23/C/12; ISBA/23/LTC/CRP.3*.

${ }^{137}$ Id., China, Response to ISA during 24th Sessions.

${ }^{138}$ Onshore mining operations and comparative domestic legislation would be ideal but are beyond the scope of this article. The author has made a submission to continue this line of research as part of a Ph.D. application at Dalhousie University and University of Ottawa. Thus, several countries under the UNCLOS will be canvassed in the first subpart. The U.S. has detailed DSM legislation.
} 
In Case 17, the SDC described due diligence as a variable concept, meaning that the standard could change as technologies improve, ${ }^{139}$ and that there should be a higher standard for riskier activities. ${ }^{140}$ The SDC continues to point out that the UNCLOS requires the sponsoring State to adopt "laws and regulations" and to take "administrative measures which are, within the framework of its legal system, reasonably appropriate for securing compliance by persons under its jurisdiction."141

Following its discussion of due diligence, the SDC outlined the "direct obligations" of sponsoring States under the UNCLOS and general international law. ${ }^{142}$ The ISA invited countries to provide the texts of their domestic legislation. ${ }^{143}$ Nauru, ${ }^{144}$ Tonga, ${ }^{145}$ and even the United States have submitted their legislation. ${ }^{146}$ Canada has not. ${ }^{147}$ Tonga, in 2017 , had a population of just over 110,000 people. ${ }^{148}$ Nauru had a population of $13,049 .{ }^{149}$ The question must be asked: How can these two small countries possibility have the legal systems in place to meet their due diligence requirements? A representative sample of several countries will be canvassed, though it is beyond the scope of this article to review every country that would have an interest in DSM in the Area.

\section{Nauru and Tonga}

The Nauru legislation is illustrative, stating that the "Sponsored Party shall be responsible for the performance of all Seabed Mineral Activities carried out within the Contract Area, and their compliance with the Rules of the ISA, and shall be liable for the actual amount of any compensation, damage or penalties arising out of its failure so to comply, or out of any wrongful acts or omissions [emphasis added] in the conduct of the Seabed Mineral Activities." 150 Section 29(2) provides indemnification for Nauru for all actions, proceedings, costs, charges, claims, and demands which may be made or brought by any third party in relation to a Sponsored Party's Seabed Mineral Activities. ${ }^{151}$ Furthermore, section 46 gives the Supreme Court jurisdiction to establish liability and to provide recourse for prompt and adequate compensation in the event of unlawful damage caused by Seabed Mineral Activities, in accordance with article $235(2)$ of the UNCLOS. ${ }^{152}$

\footnotetext{
139 Tanaka, n. 26 above, p. 210.

${ }^{140}$ Case 17, n. 20 above, para. 110.

${ }^{141}$ Id., para. 108.

142 Anton, n. 34 above, p. 248.

143 ISA, Decision of the Council of the International Seabed Authority (21 July 2011) ISBA/17/C/20, para. 3.

${ }^{144}$ Republic of Nauru, International Seabed Minerals Act, No. 26 of 2015.

145 Tonga, Seabed Minerals Act, 2014, Act 10 of 2014.

146 These include: Deep Seabed Hard Mineral Resources Act, 1980 Public Law 96-283, 28 June 1980, 94 Stat. 553 (30 U.S.C. 1401 et seq.), as amended to 1 July 2000; Deep Seabed Mining Regulations Affecting Pre-Enactment Explorers 45 Fed. Reg. 226 (20 November 1980), pp. 76661-76663; Deep Seabed Mining Regulations for Exploration Licenses 198046 Fed. Reg. 45896 (15 September 1981); 15 Code of Federal Regulations, Part 970; Deep Seabed Mining Regulations for Commercial Recovery Permits 54 Fed. Reg. 525 (6 January 1989); 15 Code of Federal Regulations, Part 971; United States Department of the Interior, Minerals Management Service (MMS). Guidelines for Obtaining Minerals other than Oil, Gas and Sulphur on the Outer Continental Shelf (Public Law 103-426, enacted 31 October 1994; 108 Stat. 4371) OCS Report. MMS 99-0070 (December 1999); In future research, a comparative analys is of the US provisions against the ISA provisions would prove useful.

${ }^{147}$ ISA, ISBA/18/C/8 Canada will be briefly mentioned below.

148 CIA World Fact Book, Tonga, People and Society, (est. July 2017), available online: $<$ https://www.cia.gov/library/publications/the-world-factbook/geos/tn.html $>$.

149 United Nations, World Population Prospects: The 2017 Revision: Nauru (United Nations Department of Economic and Social Affairs, Population Division. Retrieved 10 September 2017).

${ }^{150}$ Nauru, Act, s. 29(1).

151 Id., s. 29(2).

152 Id., s. 46.
} 
For Tonga, section 70 and section 84 of the Tonga legislation ${ }^{153}$ are similar in wording to Nauru's. Section 70(3) provides the indemnification for Tonga, while the Licensee is liable for the actual amount of any compensation or damage arising out of its failure to comply with this Act, Regulations made under this Act, or the Licence, and any "wrongful acts or omissions" [emphasis added] and those of its employees, officers, subcontractors, and agents in the conduct of the Seabed Mineral Activities or Ancillary Operations under Licence, including but not limited to that arising from injury to coastal or marine users, damage to the Marine Environment, and any related economic loss or compensation. ${ }^{154}$ Section 70(4) provides for joint and several liabilities, ${ }^{155}$ while section $70(5)$ provides for the continuation of liabilities even after all activities have ceased. ${ }^{156}$

Case 17 highlighted the need to use the precautionary approach to due diligence. ${ }^{157}$ However, both provisions in Tonga and Nauru seem to absolve themselves from this due diligence requirement. The use of "wrongful acts and omissions" is problematic, as a strict liability regime would not concern whether an act is wrongful or not to warrant a liability claim. This does not seem to be a legislative oversight, as section 109 of the Tonga legislation relates to non-interference with freedom of the high seas. ${ }^{158}$ Section 109(5), creates a "strict liability" offence. ${ }^{159}$ If section 109(4) specifically and explicitly creates a strict liability offence, yet sections 70 and 84 create a "wrongful act" liability standard, then this would preclude it from being strict liability. Finally, issues to be addressed in subsequent research include the ability to enforce this legislation, make a claim against the vessel/operator, and collect compensation awards.

\section{Singapore}

Singapore has enacted DSM legislation. In 2013, Singapore sponsored an application from a company domiciled in the country. ${ }^{160}$ The Deep Seabed Mining Act $2015^{161}$ governs Singapore's domestic DSM legislation. Singapore directly quotes the need for due diligence per section 7(1) of the legislation when it states that, before it will grant a license, the Minister must be satisfied that the company meets, or is likely to meet, the qualification standards under Annex III, Article 4 of the UNCLOS. ${ }^{162}$ Moreover, the nation requires a company to post security for the due performance of its obligations. ${ }^{163}$ Unfortunately, Singapore also requires an execution by the licensee to indemnify the nation against any liability incurred; ${ }^{164}$ however, any breaches are only subject to a fine. ${ }^{165}$

In contemplation of avoiding liabilities by using a corporate form, section 12(6) states that any transfer of license does not affect any criminal or civil liability from the original licensee. ${ }^{166}$ Section 16 provides for the government to order specific performance to prevent, contain, or minimize any harmful environmental effects. ${ }^{167}$ Finally, section 17 provides domestic enforcement of Annex III judgements. ${ }^{168}$

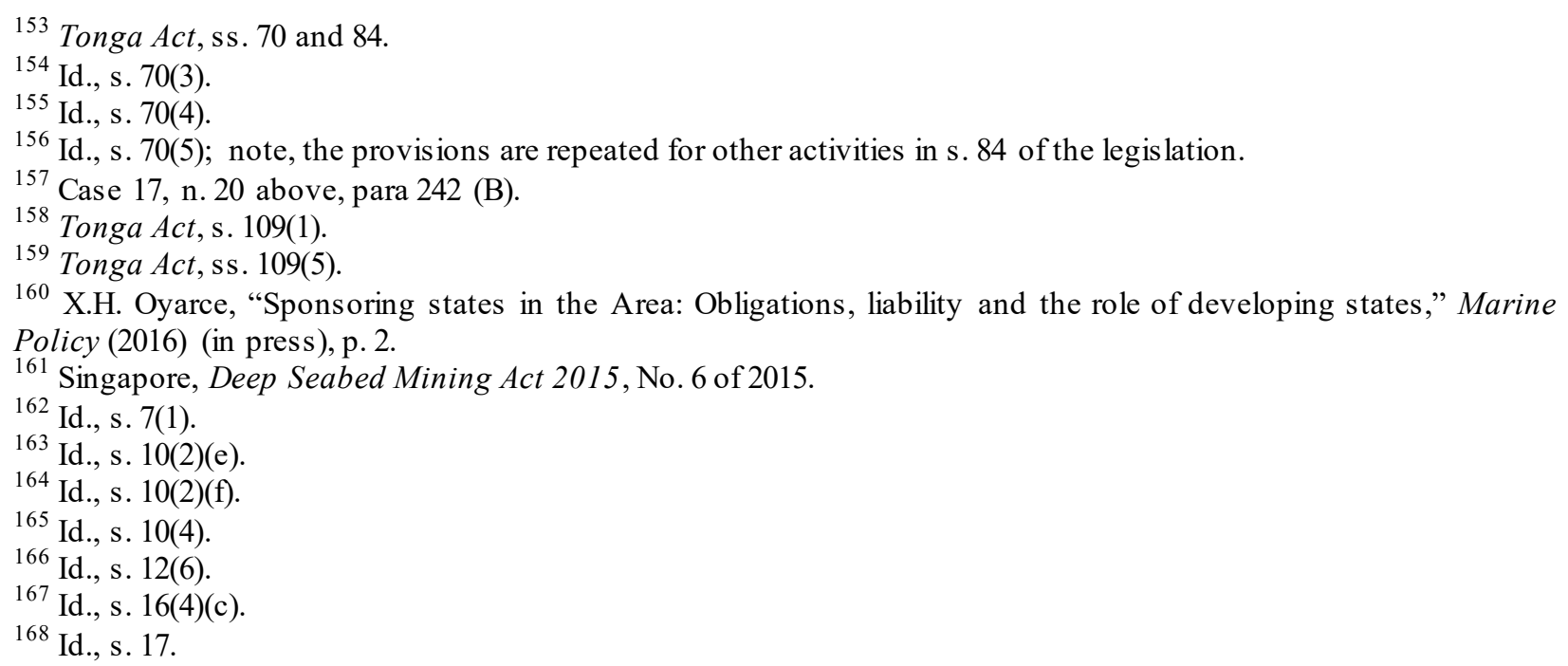


From an enforcement perspective, section 18 allows for SDC orders to be registered in Singapore, but a state may still claim privilege or immunity. ${ }^{169}$ However, the issue of strict liability for operators may not be accurate, as section 21 of the legislation requires, for an offense, to prove consent or connivance of an officer, or neglect on the officer's part. ${ }^{170}$

\section{Canada}

Given Canada's role in DSM, its familiarity with mining, offshore oil and gas, and its extension of its continental shelf claims beyond the 200 -nautical mile limits, ${ }^{171}$ it is somewhat surprising that the nation has not developed domestic legislation for DSM in the Area. ${ }^{172}$ While Canada does not have fulsome legislation, there is evidence from regulation. The Endeavour Hydrothermal Vents Marine Protected Area Regulations state:

\section{s. 2 No person shall}

(a) disturb, damage or destroy, in the Area, or remove from the Area, any part of the seabed, including a venting structure, or any part of the subsoil, or any living marine organism or any part of its habitat; or

(b) carry out any underwater activity in the Area that is likely to result in the disturbance, damage, destruction or removal of anything referred to in paragraph (a). ${ }^{173}$

This is a very strict obligation and one that could pose the question that the ISA has DSM regulation all wrong. There is an argument for goal-based regulation as used in international shipping, which will be discussed below. It also shows a potentially conflicting opinion between developed and developing countries. Developed countries have more stringent legislation.

\section{United Kingdom}

The UK legislation for DSM is the Deep Sea Mining Act, 2014 ("UK 2014 Act"). ${ }^{174}$ This legislation updates the previous legislation, the Deep Sea Mining (Temporary Provisions) Act 1981 (Temporary Act). ${ }^{175}$ The UK has significant investments in the CCZ through the UK Seabed Resourced Ltd. ${ }^{176}$ Like Singapore, the UK expressly allows for enforcement of the SDC to be taken in the UK High Court, including arbitration awards. ${ }^{177}$ Intriguingly, section 10 of the UK 2014 Act expressly omits section 10 of the Temporary Act, which had created a Deep Sea Mining Fund. The liability provisions solely deal with personal injury, not environmental damage. ${ }^{178}$ The only environmental protection stems from section 5 of

\footnotetext{
169 Id., s. 18(2).

170 Id., s. 21(1).

171 See W. Spicer, "Canada, the law of the sea treaty and international payments: Where will the money come from?," (2015) 8:31 University of Calgary SPP Research Papers, available online: $<$ https://www.policyschool.ca/wp-content/uploads/2016/03/final-law-s ea-spicer.pdf $>$.

172 The Oceans Act, SC 1996, c. 31 provides for seabed provisions within the EEZ and CS.

${ }^{173}$ Endeavour Hydrothermal Vents Marine Protected Area Regulations SOR/2003-87 s. 2.

174 Deep Sea Mining Act, 2014 (UK) 2014, c. 15.

175 Deep Sea Mining (Temporary Provisions) Act 1981, (UK) 1981 c. 53.

176 Owned in conjunction with Lockheed Martin Corp. See Lockheed Martin, "UK Government sponsors Lockheed Martin UK subsidiary for license to harvest Polymetallic Nodules." Press Release, (14 March 2013) available online: $\quad<$ https://www.lockheedmartin.com/uk/news/press -releases/2013-press-releas es/uk-government-spons orslockheed-martin-uk-subsidiary-for-licence.html>.

${ }^{177}$ UK 2014 Act, s. 9.

${ }^{178}$ Temporary Act, s. 15.
} 
the Temporary Act and deals with the grant of a license, not in the damage caused to the marine environment. ${ }^{179}$

On a positive note, there is no indemnification provision in the legislation, so the UK has not absolved itself of liability. However, the remaining sections are weak on environmental protections. The legislation seems to delegate to the ISA and the UNCLOS, all other claims for damage. This does not appear to satisfy section 235 of UNCLOS, which requires fulsome domestic legislation.

\section{China}

The final domestic jurisdiction to be canvassed is China. ${ }^{180}$ Its approach is based upon their 2016 legislation. ${ }^{181}$ China is a major player in DSM exploration, with over four exploration contracts with the ISA, ${ }^{182}$ two of which are with State-owned enterprises. ${ }^{183}$ China's legislation appears to be more complete than other nations explored, with seven chapters and 29 articles. Environmental pollution and damage to cultural relics is contained in Articles 9(3), 11, and 12. Fines for pollution/damage can range from CNY500,000 to 1,000,000, and if the illegal activities constitute a crime, criminal responsibility entails. ${ }^{184}$ The legislation itself provides for "reasonably appropriate" environmental protections, and one notable area omitted is in Environmental Assessments. ${ }^{185}$ Other fiscal arrangements are omitted, and as $\mathrm{Xu}$ notes "before exploitation activities commence, fiscal issues should be in place". ${ }^{186}$ It is unclear whether the above penalties provide limits to liabilities by the operator, although the potential for criminal charges is a novel approach. Foreign investment is omitted from the legislation. ${ }^{187}$ This would impact the effectiveness of the common heritage of mankind doctrine, as well as the practicalities of the size and scope of DSM operations.

In this summary canvass of domestic legislation, there is a broad range of theoretical approaches, and all have significant flaws and omissions. Tonga and Nauru seem to alter the strict liability to a "wrongful act" regime, and limit their own liabilities, in contrast to Case 17. The UK takes a "hands-off" approach, which seems to leave to the international system to fill in the gaps. Unfortunately, if the international system has gaps, then there is nothing to fill in. Finally, China's legislation seems to cap liabilities, ${ }^{188}$ so it may not compensate for the environmental harms caused. However, some evidence from their approach to oil spills may provide clarity.

\section{PART 4 - LESSONS FROM OTHER INTERNATIONAL REGIMES}

\footnotetext{
179 Id., s. 5

${ }^{180}$ Unfortunately, the links to the actual texts are in Mandarin/Chinese. As such, the article will use third party peer reviewed articles for its analysis.

${ }^{181}$ Deep Seabed Area Resource Exploration and Exploitation Law of the People's Republic of China (hereinafter "Deep Seabed Law") promulgated 26 Feb. 2016, entered into force 1 May 2016, adopted at the 19th Session of the Standing Committee of the 12th National People's Congress (NPC) of China, Order No. 42 of the President of the People's Republic of China (PRC).

182 G. Zhang and P. Zheng, "A new step forward: Review of China's 2016 legislation on international seabed area exploration and exploitation," Marine Policy 73 (2016): 244-255, p. 246.

${ }^{183}$ X. Xu, G. Zhang and G.J. Xue, "China's deep seabed law: Towards "reasonably appropriate" environmental legislation for exploration and exploitation of deep sea minerals in the Area," Asian Yearbook of International Law 21 (2015), available online: <https://brill.com/abstract/book/edcoll/9789004344556/B978-90-04-344549 012.xml>.

${ }^{1 \overline{84}}$ Zhang and Zheng, n. 182 above, p. 250.

${ }^{185} \mathrm{Xu}$ et al., n. 183 above; Of note, a lack of EA was also at is sue in the Philippines -China dispute below. Whether this is a result of the case, or whether China believes the ISA will create the required EA is up for discussion.

${ }^{186} \mathrm{Id}$.

187 Zhang and Zheng, n. 182 above, p. 251.

${ }^{188}$ Bulong, n. 122 above, p. 177.
} 


\section{Civil Liability Regimes}

There are several relevant international conventions that deal with liability for damage to the marine environment. The Protocol to Amend the International Convention on Civil Liability for Oil Pollution Damage (CLC) provides for strict liability on the part of the registered owner of the tanker to pay compensation for "pollution damage." 189 The CLC explicitly uses the term "negligence." ${ }^{190}$ It also raised the limits of liability, established a compulsory insurance requirement, and introduced the possibility of a direct action against the insurer. ${ }^{191}$ Norway would appear to be the only state that has extended its application of the CLC (as implemented nationally) to oil pollution on the high seas; that action benefits both the environment and the polluting ship-owner. ${ }^{192}$

The International Oil Pollution Compensation Funds are a key component of this strict liability regime. Claims from the Torrey Canyon spill, to which compensation was only available via international maritime law, required a claim of negligence and gave the ship-owner the right to limit liability to amounts deemed insufficient. ${ }^{193}$ The Fund created a levy system and explicitly covers compensation for reasonable measures to reinstate an environment to its pre-contaminated state. ${ }^{194}$

In this regard, China's updated legislation is illustrative. Section 66 of the Marine Environmental Protection Law, $1999^{195}$ created the compensation fund for vessel oil pollution, and the 2010 regulations increased liability limits and made insurance mandatory. ${ }^{196}$ This fund is a key and critical component of environment protections, as it applies when the damage exceeds the operator's liability and/or ability to pay, when the operator is exempted from liability, and when the source of pollution cannot be ascertained. ${ }^{197}$ Compensation for vessel source oil pollution plays an essential role in protecting the interests of victims and in the prevention of oil pollution. ${ }^{198}$ This is a glaring flaw in the DSM regime.

The International Convention on Civil Liability for Bunker Oil Pollution Damage, $200{ }^{199}$ was adopted to ensure that adequate, prompt, and effective compensation is available to persons who suffer damage caused by spills of oil, when the oil is carried as fuel in ships' bunkers. ${ }^{200}$ This convention applies to damage caused to the territory, including the territorial sea, and in exclusive economic zones of States Parties. ${ }^{201}$ Another key provision is the requirement for direct action. This would allow a claim for compensation for pollution damage to be brought directly against an insurer. ${ }^{202}$

189 Protocol to Amend the International Convention on Civil Liability for Oil Pollution Damage, 1969 , (27 November 1992) 1956 United Nations Treaty Series 255 (CLC 1992).

190 Id.

${ }^{191}$ T.J. Schoenbaum, "Liability for damages in oil spill accidents: Evaluating the USA and international law regimes in the light of Deepwater Horizon," Journal of Environmental Law 24, no. 3 (2012): 395-416

192 Comité Maritime International, International Working Group (Polar Shipping) Civil Liability (31 October 2017) L. Rosenberg-Overby ed. (CMI, online, 2017), p. 41.

193 R.H. Ganton, "The international oil pollution compensation fund," Environmental Policy and Law 12 (1984): 59, p. 6.

194 J. Wren, "Overview of the compensation and liability regimes under the international oil pollution compensation fund (IOPC)," Spill Science \& Technology Bulletin 6, no. 1 (2000): 45-58, p. 48.

195 See L. Zhu, B. Dong and K.X. Li, "China's 2012 regime for compensation for vessel source oil pollution: A comparative study," Ocean Development \& International Law 44, no. 3 (2013): 270-286.

196 Amended Regulations of the People's Republic of China on the Prevention and Control of Marine Pollution from Ships (Amended Regulations; Measures for Implementation of Insurance Civil Liability of Oil Pollution from Ships (Oil Pollution Insurance Regulation), article 56.

197 Administrative Measures for Use and Collection of the Vessel-Source Oil Pollution Compensation Fund, China Article 15.

198 Zhu et al., n. 195 above, p. 405.

199 International Convention on Civil Liability for Bunker Oil Pollution Damage, 2001 (23 March 2001).

${ }^{200}$ Id., Article 3.

${ }^{201}$ Id., Article 2.

${ }^{202}$ Id., Article 7 provides for compulsory insurance. 
The not-yet in force 2010 Hazardous and Noxious Substances Convention ${ }^{203}$ (HNS) sets out a shared liability regime to compensate claimants for damages arising from the international or domestic carriage of HNS by seagoing vessels. ${ }^{204}$ It has both ship-owners liability and an HNS Fund provision. ${ }^{205}$ The ship-owners liability is a strict liability regime, while the HNS liability is either a negligence standard or, if the ship-owner cannot pay, a strict liability standard. ${ }^{206}$

This convention would greatly expand liability, compared to Canadian domestic legislation, from a maximum of CA $\$ 16$ million to CA $\$ 74$ million (for a 20,000 tonne ship) and a total maximum liability of CA $\$ 500$ million. ${ }^{207}$ This is another example of how domestic legislation may be insufficient to cover the harms to the environment. However, the Canadian approach has a wider scope than the international regime and pays on claims having to do with both persistent oil and non-persistent oil pollution discharged from all classes of ships. ${ }^{208}$

The main takeaway is that various international agreements provide for strict liability for environmental damage. The evidence seems to indicate that the number of oil spills and the amount of oil that has been discharged has declined over the last number of years. ${ }^{209}$ Yet, the phrasing of the Draft Regulations and domestic legislation seems to provide for a "wrong act or omission" standard.

The United States is the most significant maritime nation that has chosen not to be a party to the UNCLOS and instead has developed its own national law concerning liability for oil pollution damages. ${ }^{210}$ In the United States, the Deepwater Horizon Oil Spill demonstrated the consequences of a major environmental disaster in the marine environment. ${ }^{211}$ The case illustrated domestic liability legislation and certain issues with the concept of "pure economic loss." 212

The United States imposes a strict liability without fault on all responsible parties for oil discharges. $^{213}$ Responsible parties include the owner, operator, or charterer of a vessel, the owner or operator of an onshore oil facility; the lessee, permittee, and owner and operator of any offshore facility; the owner and operator of a pipeline; and the licensee of a deep-water port. ${ }^{214}$ Furthermore, the United States has created an Oil Spill Liability Trust Fund. ${ }^{215}$

The United States is not a party to the UNCLOS, so it will be interesting to note their DSM activities, and their liabilities for environmental damage should be involved as either a vessel State, a flag State, or a port/processing State. However, it is this type of legislation that is required; strict and unlimited liability for all parties, with an environmental liability fund if damages are larger than one party can or will pay. ${ }^{216}$

In summation, the civil liability regimes provide great evidence as to the correct approach for DSM liability. The regulations are clear, provide for strict liability for operators, and no indemnification

203 International Convention on Liability and Compensation for Damage in Connection with the Carriage of Hazardous and Noxious Substances by Sea, 2010 (HNS Convention).

204 Transport Canada, Maritime Transport of Hazardous and Noxious Substances: Liability and Compensation Discussion Paper (October 2010) (Ottawa: Transport Canada, 2010).

${ }^{205}$ HNS Convention, n. 203 above, Part II, Article 7.

206 Transport Canada, n. 200204 above, p. 8.

${ }^{207}$ Id., p. 13

${ }^{208}$ Zhu et al., n. 195 above, p. 277.

209 C. Kontovas, H. Psaraftis and N. Ventikos, "An empirical analysis of IOPCF oil spill cost data," Marine Pollution Bulletin 60 (2010): 1455-1466, p. 1456.

${ }^{210}$ T.J. Schoenbaum, "Liability for damages in oil spill accidents: Evaluating the USA and international law regimes in the light of Deepwater Horizon," Journal of Environmental Law 24, no. 3 (2012): 395-416, p. 397.

211 A. Davis, "Pure economic loss claims under the Oil Pollution Act: Combining policy and congressional intent," Columbia Journal of Law and Social Problems 45, no. 1 (2011): 1-44

212 Id., p. 3.

21333 USC ss. 2701 and 2702, see also Schoenbaum, n. 210above, p. 398.

214 Id., s. 2701.

215 Oil Spill Liability Trust Fund, 25 USC s. 9509; See also 46 USC s. 4611.

216 The U.S. has DSM legislation. See n 146 above. 
for State parties. Furthermore, the technology fund provides for the extra bit of "insurance" to ensure that there are funds to clean up any environmental spill. ${ }^{217}$

\section{Exclusive Economic Zone and Continental Shelf Provisions}

As noted in Part 1, the Solwara 1 in PNG's EEZ could be highly comparative to DSM in the Area. Unfortunately, PNG does not have any laws on DSM in the EEZ that would regulate Solwara $1 .{ }^{218}$ Thus, both PNG and Nautilus may work with "environmental impunity." 219 While a limited amount of onshore processing will occur in PNG, the majority of processing will occur in China. ${ }^{220}$ One potential saving grace is, as previously noted, that Nautilus is a Canadian company and listed under the TSX. The provincial securities acts, for example in British Columbia, ${ }^{221}$ and the TSX require certain mandatory disclosures and risk assessments, and investors should be cognizant of potential company liabilities. ${ }^{222}$ At the date of writing, the project is showing significant financial hurdles. In December, 2017, a citizens group, represented by the Centre for Environmental Law and Community Rights Inc. (Celcor) and assisted by the New South Wales Environmental Defenders Office commenced a lawsuit against PNG claiming insufficient EA procedures for the project. ${ }^{223}$ There is thus significant uncertainty about if this project will begin.

New Zealand has a novel approach to DSM, at least within its EEZ. Their legislation, The Exclusive Economic Zone and Continental Shelf Act (Environmental Effects) 2012 ("NZ Act"), ${ }^{224}$ provides that non-discharge offenses are subject to strict liability. ${ }^{225}$ DSM in the EEZ was considered in the Trans-Tasman Resources Ltd. Marine Consent Decision, ${ }^{226}$ and highlighted the uncertainty of the determination of costs of potentially adverse effects. ${ }^{227}$ In the face of this uncertainty, the use of the

217 The SDC recommended the ISA implement a trust fund; see Case 17, n. 21 above, para. 205 and UNCLOS, s. $235(3)$.

218 Bulong, n. 122 above, p. 175.

219 Id., p. 175.

220 R. Steiner, Bismarck-Solomon Seas Indigenous Peoples Council, Independent Review of the Environmental Impact Statement for the Proposed Nautilus Minerals Solwara 1 Seabed Mining Project, Papua New Guinea, 3 (Jan. 10, 2009),

221 Securities Act, RSBC 1996, c. 418 ss. 131, 140.3, 63. BC was used as an example because Nautilus is registered in $\mathrm{BC}$.

${ }^{222}$ These include Standards of Disclosure for Mineral Projects, BSSC NI 43-101 (9 May 2016), Continuous Disclosure Obligations, BCSC NI 51-102 (30 June 2015); All documents required must be posted on http://www.sedar.com which is the system for electronic documents and retrieval. $<\mathrm{https}: / /$ sedar.com/DisplayCompanyDocuments.do?lang=EN\&is suerNo=00005833 $>$.

223 See H. Davidson, “Troubled Papua New Guinea deep-sea mine faces environmental challenge," (11 December 2017) Press Release, The Guardian, available online: <https:/www.theguardian.com/world/2017/dec/12/troubledpapua-new-guinea-deep-sea-mine-faces-environmental-challenge $>$.

${ }^{224}$ Exclusive Economic Zone and Continental Shelf (Environmental Effects) Act 2012, No. 72 (2012) (New Zealand) There is another piece of domestic legislation the Crown Minerals Act 1991, No. 70 (NZ) that comprises the onshore mining provisions.

${ }^{225} \mathrm{Id}$.

226 NZ Environmental Protection Authority, Trans-Tasman Resources Ltd. Marine Consent Decision, (17 June 2014) available online: <http:/www.epa.govt.nz/EEZ/EEZ0O0004/Trans TasmanResources >.

${ }^{227}$ Id., para. 753. 
precautionary approach is mandated, but even this approach has "no easy answers." 228 The license was granted, but it is currently under appeal. 229

The Trans-Tasman case may have implications for DSM in the Area, as adequate information on the effects on the environment, monitoring baseline data, and adaptive management approaches are required. ${ }^{230}$ This could all have implications on the due diligence requirement from Case 17. There is another interesting issue with liability - the ability to collect. According to Makgill, "in practical terms, the ability to recover damages is likely to be governed by the financial resources available to those liable." 231 As a valid example, Nautilus is having significant financial obstacles, and without an environmental trust fund or significant insurance policies in place, it is unlikely that any environmental damage claim, even if awarded, could be collected. The ISA needs to take action.

\section{Flag State Liabilities}

Many boundary questions remain, including the line between flag State and sponsoring State liability. ${ }^{232}$ Flag State liabilities arise from Articles 209(2), 211 and Article 217 of the UNCLOS. Article 209(2) states that flag States shall adopt laws to prevent, reduce, and control pollution from vessels flying under their flag. ${ }^{233}$ States shall ensure compliance of vessels flying under their flag. ${ }^{234}$ However, there is a lack of full clarity to their application to DSM in the Area and on the standard of liability and amount of damages that a flag State could face, should environmental damage occur due to DSM. Thus, international law precedent on liabilities of flag States and on operators from other settings would prove useful in the DSM context.

On April 2, 2015, the International Tribunal for the Law of the Sea rendered an advisory opinion on the rights and obligations of flag States and coastal States regarding illegal, unreported, and unregulated ("IUU") fishing within the EEZ (Case 21). ${ }^{235}$ Ownership of fishing vessels also comprises a "complex structure of nominated front companies and/or non-disclosed beneficial owners." 236 The tribunal noted that flag States have a "due diligence" obligation to ensure that vessels sailing under their flag take the necessary measures to comply with the protection and preservation measures adopted by member states. ${ }^{237}$ The State must also have domestic legislation to enforce these rules. ${ }^{238}$

More importantly, the Tribunal in Case 21 relied heavily on Case 17 to advance its jurisprudence. ${ }^{239}$ Like Case 17, the standard of liability for flag States arises not out of the actions of the operator, but in the failure to comply with its due diligence obligation. ${ }^{240}$ The Tribunal noted:

228 D.K. Anton and K.E. Kim, "The application of the precautionary and adaptive management approaches in the seabed mining context: Trans-Tasman Resources Ltd. marine consent decision under New Zealand's Exclusive Economic Zone and Continental Shelf (Environmental Effects) Act 2012," International Journal of Marine and Coastal Law 30 (2015): 175-188, p. 185.

229 NZ EPA, Ref EEZ000011, Notice of Date of Call, Judges Chambers List, available online: $<$ https://www.epa.govt.nz/public-consultations/decided/trans-tasman-resources-limited-2016/>.

${ }^{230}$ Id., p. 187.

231 R. Makgill, "Oil and gas in the exclusive economic zone," Resource Management Journal, April (2014): 29-31, p. 31 .

${ }^{232}$ Phillips, n. 110 above, p. 3.

${ }^{233}$ UNCLOS, n. 1 above, s. 209(2).

${ }^{234}$ Id., Article 217(1).

235 Request for an Advisory Opinion Submitted by the Sub-Regional Fisheries Commission (SRFC), Case No. 21, Advisory Opinion (ITLOS, 2 April 2015). Documents relating to the case available online: $<$ http://www.itlos.org/cases/list-of-cases/case-no-21/>.

${ }^{236}$ L. Griggsa and G. Lugten, "Veil over the nets (unravelling corporate liability for IUU fishing offences," Marine Policy 31 (2007): 159-168, p. 160.

${ }^{237}$ Case 21, n. 235 above, para. 136.

238 Id., para. 138.

239 Id., paras, 126 and 131.

${ }^{240} \mathrm{Id}$., para. 146. 
Although the relationship between sponsoring States and contractors is not entirely comparable to that existing between the flag State and vessels flying its flag which are engaged in fishing activities in the exclusive economic zone of the coastal State, the Tribunal holds the view that the clarifications provided by the Seabed Disputes Chamber regarding the meaning of the expression "responsibility to ensure" and the interrelationship between the notions of obligations "of due diligence" and obligations "of conduct" referred to in paragraph 129 are fully applicable in the present case. ${ }^{241}$

Thus, flag State liabilities are the same as sponsoring State liabilities, in that it is their responsibility to ensure to deploy the adequate means and exercise best possible efforts to obtain this result. ${ }^{242}$ The liability of the flag State arises from a failure to comply with its "due diligence" obligations. ${ }^{243}$

The issue of flag State liability also arose in the China-Philippines dispute. ${ }^{244}$ The tribunal stated that anything less than a due diligence standard by the flag State to avoid IUU would fall short of the UNCLOS. ${ }^{245}$ Moreover, as there is such a close link between Chinese fishing vessels and the Chinese government, there is a heightened obligation on the part of the flag State. ${ }^{246}$

This case is relevant to DSM due to the marine environmental protection obligations of flag States. The obligations noted in China-Philippines apply to flag States regardless of the location of the harmful activities; thus, jurisdiction is not dependent on sovereignty or the existence of an EEZ ${ }^{247}$ It also displays the extent of how an EA would fulfill a due diligence defense. The Draft Regulations provide for a need for an EA to be granted a license to conduct DSM in the area. Case 17 specifically noted that due diligence requirements will differ based on the type of mining. China-Philippines could provide evidence as to the extent of the requirements, specifically with the use of EA. China-Philippines noted that the existence (or lack thereof) of an EA is important, but it is not definitive in determining whether there is a breach of its requirements under Article 206. ${ }^{248}$ Moreover, China's DSM firms are state-controlled operations, and thus the flag State, sponsoring State, and operator all may be deemed the same and have higher obligations for liability. ${ }^{249}$ EAs should assist in meeting a due diligence threshold, but by themselves they may not absolve a flag State from liability.

\section{PART 5 - ANALYSIS AND RECOMMENDATIONS}

Much more work needs to be conducted to ensure that fulsome liability provisions are in place for DSM in the Area. The liability regime should reflect a transnationalist approach with a stewardship doctrine. Thus, the use of the Precautionary Principle makes abundant sense, especially because of scientific uncertainty. When taken in context with the Sustainable Development Goals and the "common heritage of

\footnotetext{
${ }^{241}$ Id., para. 125.

242 Id., para. 128

243 Id., para. 146.

244 Permanent Court of Arbitration, In the Matter of the South China Sea Arbitration, PCA Case No 2013-19, Award (12 July 2016).

245 Id., p. 294.

246 Id., p. 297.

247 Id., para. 927; moreover, the tribunal noted that Part XII applies to all maritime areas, both inside national jurisdiction and outside it. Again, sovereignty is irrelevant, see PCA para. 940. This would presuppose that these is sues would apply to DSM in the Area.

248 Id., para. 991; the PCA directly quoted the passage from Case 17 comparing Article 206 with EA requirements, para. 948 .

${ }^{249}$ Id., paras. 965 and 971.
} 
mankind," this makes an even more compelling argument. According to the Sustainable Development Goal 14, the oceans and seas are to be conserved and developed in a sustainable manner. ${ }^{250}$

\section{Ope rators}

Operator liability seems to depend on the definition of a "wrongful act or omission," the language used in the UNCLOS and the Draft Regulations. Case 17 highlighted the need for different due diligence standards for different types of mining. This may have inadvertently tipped the hand that the strict liability will not be enforced, even for contractor/operators. This regime seems to lead back to the general international maritime law surrounding environmental damage.

To answer, some evidence is provided by the Draft articles on Responsibility of States for Internationally Wrongful Acts (Draft Articles). ${ }^{251}$ While not in force, and applicable to state parties, these Draft Articles may assist in articulating the elements of the offense. Article 2 states that there is an internationally wrongful act of a State when conduct consisting of an action or omission: (a) is attributable to the State under international law; and (b) constitutes a breach of an international obligation of the State. ${ }^{252}$ Unfortunately, the accompanying commentaries determine that the interpretation of a breach may be subjective (i.e., with intent or knowledge) or objective (i.e. inadvertence or negligence). ${ }^{253}$ Thus, the offense may be both intentional and negligent. Either definition seems to preclude strict liability. If negligence is the standard, then there is also a due diligence defense. And, as Case 17 noted, due diligence may depend on the quality of the Environmental Assessments (EA) conducted.

Environmental Assessments (also known as Environmental Impact Assessments) are used to anticipate, assess, and reduce environmental and social risks from a project. ${ }^{254}$ The ISA requires an EA for the Area, ${ }^{255}$ but it is not a robust regime. ${ }^{256}$ There are several accepted criteria for a fulsome EA process. This process includes screening, scoping, EA, environmental management plans, external reviews by experts, public stakeholder consultations, and regulatory reviews. ${ }^{257}$ EA standards may also limit liability based on the Draft Regulations. If the Operator has an EA approved by the ISA, but environmental damage occurs, then it is unclear whether the operator will be liable, absent a "wrongful act or omission."

The Environmental liability and common heritage may be at odds.

Even where adherence to international rules is demonstrated, there would remain potential for inconsistent interpretation and application of those rules that may need to be resolved. As a consequence, there will be a need for both vertical (Authority - sponsoring state) and horizontal (between sponsoring states) harmonization of EA processes and related compliance action to avoid conflicting directions and duplication. ${ }^{258}$

${ }^{250}$ UNGA, Transforming our World: the 2030 Agenda for Sustainable Development, Sustainable Development Goals, (21 October 2015) A/RES/70/1, Goal 14: Conserve and sustainably use the oceans, seas and marine resources

251 International Law Commission, Draft articles on Responsibility of States for Internationally Wrongful Acts, Yearbook of the International Law Commission 2:2 (2001) (A/56/10)

252 Id., Article 2.

${ }^{253}$ Id., Commentary to Article 2, subsection (2), p. 34.

254 J.M. Durden et al., "Environmental impact as sessment process for deep-sea mining in 'the Area'," Marine Policy 87 (2018): 194-202.

255 Draft Regulations, n 89 above, Regulations 18, 19, 20

256 J.M. Durden et al., "A procedural framework for robust environmental management of deep-s ea mining projects using a conceptual model," Marine Policy 84 (2017): 193-201.

${ }^{257}$ Durden et al., n. 254 above, p. 196.

258 N. Craik, ISA Discussion Paper No 4, Enforcement and Liability Challenges in the Regulation of Deep Seabed Mining (Jamaica, ISA, 2016), p. 10. 
The ability to pay is also very much in question. Interoceanmetal's casual observation is relevant. They stated that the insurance industry may not be ready to make a policy. Moreover, as will be detailed in a follow-up research paper, it is difficult to conceive of how such a policy would take place, given the unknown liability, amount of damage, limit on liability, indemnification of sponsoring States, and other factors. As a matter of international law, it seems that every State has the right to combat pollution on the high seas, but no existing legal regime appears to provide for compensation. The ISA needs to clarify liabilities of operators, create a levy system to create a fund, and assist the insurance industry to create DSM policies. In other words, the international community, through the civil liability regimes discussed above, have created a mutually beneficial solution that benefits both the environment and the business community. The ISA should follow this solution for DSM. Unfortunately, through domestic legislation, liability seems to be going in the opposite direction.

\section{Spons oring States}

Case 17 is the representative precedent for sponsoring State liability. It is also clear that there should be no distinction of liability for developing or developed States. ${ }^{259}$ To use a somewhat colloquial comparison, "with great power comes great responsibility." ${ }^{260}$ Countries want to harvest and exploit the minerals on the DSB, but in terms of the Area, they do not want to have any liabilities and have legislated indemnifications for any liability that is due. This seems inherently contradictory to Case 17 and the due diligence defense, and the protection of the environment. The watering down from a State needing to take all steps necessary to only reasonable steps necessary shows a weakening of environmental protections.

Domestic legislation does not assist in the matter and may further weaken environmental protections. Nauru and Tonga seem to completely absolve themselves of any liability. The UK takes a hands-off approach, seemingly leaving it to the ISA. The United States takes a strict liability approach, at least with EEZ and oil spill legislation. New Zealand takes a very precautionary approach, both with EEZ and in the Area. Singapore takes a middle ground. Belgium may have a point - there is a real potential of sponsors shopping to avoid liability. This contradicts the necessity of sections 209 and 235 of the UNCLOS, requiring domestic legislation and enforcing compensation claims.

The biggest unknown still is in compensation claims if operators cannot or will not pay. The indemnification clauses, pragmatically, are only relevant if the operator has the financial means. A compulsory insurance regime and a levy based environmental fund would solve many of these issues. Plakokefalos notes "it remains to be seen how the Opinion will play out in the unfortunate case where damage in the Area does occur and how the States will react to it in their subsequent practice." 261

\section{Flag States}

While there are similarities between flag States and sponsoring States, there are significant differences. ${ }^{262}$ The Solwara 1 case is again illustrative. Nautilus does not own the ship but is chartering the ship from Dubai. UNCLOS section 91(1) states that there must be a genuine connection to register a vessel. Moreover, the flag State must exercise effective jurisdiction over the vessel. ${ }^{263}$ Cases 17, 21, and the China-Philippines Arbitration seem to indicate that a flag State also may be liable if they fail in their obligations to oversee the vessel. The due diligence defense seems to be the same as those of the

\footnotetext{
${ }^{259}$ Oyarce, n. 160 above, p. 3.

260 W. Lamb, "Habeas Corpus Suspension Bill," The Parliamentary Debates from the Year 1803 to the Present Time, Volume 36, Comprising the Period from the Twenty-Eight Day of April to the Twelfth Day of July, 1817, (27 June 1817) Start Column Number 1225, Quote Column Number 1226 and 1227, Published Under the Superintendence of T.C. Hansard, Fleet Street, London.

${ }^{261}$ Plakokefalos, n. 28 above, p. 136.

262 Oyarce, n. 160 above, p. 3.

${ }^{263}$ UNCLOS, n. 1 above, s. 94.
} 
sponsoring state. However, there is no domestic legislation specifically required for flag States as it relates to DSM in the Area. Dubai/the UAE, for instance, does not have DSM legislation.

As Case 17 noted, due diligence depends on the type of mining. The requirements of EA may provide evidence of meeting this obligation. But, given China's omission of EA in their domestic legislation and given the response of the tribunal in PCA, they could breach the requirements of Articles 209 and thus not meet their liability requirements. The ISA needs to create specific EA standards for each type of mining and clarify how they differ in order for sponsoring and flag States to meet their obligations.

\section{International Se abed Authority}

The ISA is a party to potential DSM environmental claims and thus could be liable. The "wrongful act" provides the requisite standard, and it seems to have the due diligence defense as per Case 17. Case 21 also noted liability of an international organization. ${ }^{264}$ In Case 21 , it was the organization that granted fishing licenses. This would be akin and comparable to the ISA, which grants exploration and exploitation licenses. The indemnification clause in section 8.2 of the Draft Regulations, however, weakens this standard, without creating a mechanism by which operators may actually have the financial capabilities of indemnifying the other parties.

The ISA states that it is in agreement with environmental protections and the precautionary approach, at least in theory. The ISA has reaffirmed its position on the environment in its strategic plan. ${ }^{265}$ Unfortunately, these positions do not specifically state that they will ensure the effective cleanup and remediation of any environmental damage, should it occur, nor ensure that there are funds available to assist with the remediation. Whether or not the ISA retains any residual liability remains unknown.

\section{CONCLUSION}

The evidence all indicates that there are still too many unknowns to proceed with exploitation of DSM in the Area without further developing the legal obligations of all parties. The ISA is in a powerful position to grant licenses. It needs to take a step back, develop much more robust regulations to prevent environmental damage, and ensure that remediation of the environment can take place if environmental damage occurs. Currently, there is no mechanism for this assurance.

There is a real concern that the Draft Regulations will be watered down due to certain Asian and developing countries' concerns, as shown by the responses in the 24th Session of the ISA. With the ISA aiming for a July, 2018, release of the next round of Draft Regulations, in time for Part 2 of the 24th session of the ISA on July 24, 2018 there does not appear to be enough time or appetite to make the regulations more stringent. The lack of an environmental fund is the most glaring omission. This is an oversight and potentially hazardous outcomes may result.

On November 15, 2017, the UN General Assembly Resolution A/72/L.7 convened a conference for 2018, 2019, and 2020 to discuss the implementation of a binding agreement on the conservation and sustainable use of marine biological diversity of areas beyond national jurisdiction. ${ }^{266}$ This would include the Area and would have repercussions for DSM. The ISA needs to take the outcomes of this conference and ensure that that protection of the marine environment in the Area is protected.

\footnotetext{
${ }^{264}$ Case 21, n. 235 above, para. 156.

265 ISA, Draft Strategic Plan V2.1, (26 February 2018) at SD3 (Jamaica, ISA) available online: $<$ https://www.isa.org.jm/files/documents/EN/SPlan/SP-en.pdf $>$.

266 UN General Assembly, A/72/L.7 Seventy second session, Agenda no 77, 15 November 2017, International legally binding instrument under the United Nations Convention on the Law of the Sea on the conservation and sustainable use of marine biological diversity of areas beyond national jurisdiction.
} 
It seems like "the tail is wagging the dog," in that the technology seems to be determining the law, rather than the law determining the liability. ${ }^{267}$ Clearly, the international community can do better. The civil liability regimes provide such evidence. DSM is potentially destructive to the environment and much more work is required. The current liability regime is too weak and too unknown to provide a framework for such a large-scale industry.

${ }^{267}$ Case 17, n. 20 above, para. 136. 